\title{
Health Risk and Environmental Assessment of Cement Production in Nigeria
}

\author{
Mmemek-Abasi Etim ${ }^{1, *(\mathbb{D}) \text {, Kunle Babaremu }}{ }^{2}$, Justin Lazarus ${ }^{1}$ and David Omole ${ }^{1}$ \\ 1 Department of Civil Engineering, College of Engineering, Covenant University, Ota 112233, Nigeria; \\ lazarus.justin@covenantuniversity.edu.ng (J.L.); david.omole@covenantuniversity.edu.ng (D.O.) \\ 2 Directorate of Pan African University for Life and Earth Science Institute, University of Ibadan, \\ Ibadan 200284, Nigeria; kunle.babaremu@paulesi.org.ng \\ * Correspondence: mmemek-abasi.etim@stu.cu.edu.ng
}

Citation: Etim, M.-A.; Babaremu, K.; Lazarus, J.; Omole, D. Health Risk and Environmental Assessment of Cement Production in Nigeria. Atmosphere 2021, 12, 1111. https://doi.org/10.3390/ atmos12091111

Academic Editor: Deborah Traversi

Received: 19 July 2021

Accepted: 11 August 2021

Published: 30 August 2021

Publisher's Note: MDPI stays neutral with regard to jurisdictional claims in published maps and institutional affiliations.

Copyright: (C) 2021 by the authors. Licensee MDPI, Basel, Switzerland. This article is an open access article distributed under the terms and conditions of the Creative Commons Attribution (CC BY) license (https:// creativecommons.org/licenses/by/ $4.0 /)$.

\begin{abstract}
The cement manufacturing industry has played a fundamental role in global economic development, but its production is a major facilitator to anthropogenic $\mathrm{CO}_{2}$ release and solid waste generation. Nigeria has the largest cement industry in West Africa, with an aggregate capacity of 58.9 million metric tonnes (MMT) per year. The Ministry for Mines and Steel Development asserts that the nation possesses total limestone deposits of around 2.3 trillion MT with 568 MMT standing as established reserves and 11 MMT used. Cement industries are largely responsible for releasing air pollutants and effluents into water bodies with apparent water quality deterioration over the years. Air pollution from lime and cement-producing plants is seen as a severe instigator of occupational health hazards and work-related life threats, negatively affecting crop yields, buildings, and persons residing in the vicinity of these industries. World Bank observed in 2015 that $94 \%$ of the Nigerian populace is susceptible to air pollutants that surpass WHO guidelines. In 2017, World Bank further reported that 49,100 premature deaths emanated from atmospheric $\mathrm{PM}_{2.5}$, with children beneath age 5 having the greatest vulnerability owing to lower respiratory infections, thereby representing approximately $60 \%$ of overall $\mathrm{PM}_{2.5}$-induced deaths. Cement manufacturing involves the significant production of $\mathrm{SO}_{2}, \mathrm{NO}_{\mathrm{x}}$, and $\mathrm{CO}$ connected to adverse health effects on humans. Sensitive populations such as infants, the aged, and persons having underlying respiratory ailments like asthmatics, emphysema, or bronchitis are seen to be most affected. Consequently, in addressing this challenge, growing interests in enacting carbon capture, usage, and storage in the cement industry is expected to alleviate the negative environmental impact of cement production. Still, no carbon capture technology is yet to achieve commercialization in the cement industry. Nonetheless, huge advancement has been made in recent years with the advent of vital research in sorption-enhanced water gas shift, underground gasification combined cycle, ammonium hydroxide solution, and the microbial-induced synthesis of calcite for $\mathrm{CO}_{2}$ capture and storage, all considered sustainable and feasible in cement production.
\end{abstract}

Keywords: cement production; particulate matter $\left(\mathrm{PM}_{2.5}\right.$ \& $\left.\mathrm{PM}_{10}\right)$; carbon capture; public health; air pollution; water pollution

\section{Introduction}

Cement is the most common and extensively used adhesive in the construction industry. It is employed on highways, houses, embankments, bridges, commercial establishments, and flyovers. Hence, the cement manufacturing industry has played a fundamental role in global economic development, with construction, steel, crude oil, iron, and telecommunications, constituting major infrastructural aspects worldwide. Swift commercialization, urban civilization, and the necessity to boost domestic goods production have been the lead cause for the surge in cement production [1]. In Nigeria, the availability of raw materials has encouraged numerous local productions. As of 2013, annual cement 
production increased significantly above $1300 \%$, from below 2 million tonnes in 1990 to above 28 million tonnes in 2013 [2]. Cement is a powder-like material comprising lime and mud-clay as fundamental elements, utilized in all kinds of building and civil constructions. The used clay provides silica, iron oxide, and alumina, while the calcined lime principally gives calcium-oxide. As highlighted in Table 1, raw materials used for cement production are obtained by blasting rock quarries with explosives [3,4]. The blasted rocks are transported to the plants, where they are crushed into chunks of $\frac{1}{2}$ inch-sized particles. Through the process of prehomogenization, cement is produced depending on the needed proportion of ground clay and limestones. For a pressurized rotatory furnace of around $1400{ }^{\circ} \mathrm{C}$, these unprocessed resources (Table 1 ) are calcined to become a clinker [3,5]. The clinker is then pulverized with some minerals to a powder to produce Portland cement [4]

Table 1. Raw materials used for clinker production.

\begin{tabular}{ll}
\hline Calcium, Ca & $\begin{array}{l}\text { Limestone involving quick-lime from treating } \\
\text { wastewater, caustic-lime }\end{array}$ \\
\hline Silicon, $\mathrm{Si}$ & $\begin{array}{l}\text { Sand such as harnessed mould (silica } \\
\text { sand-clay-liquid mixture) }\end{array}$ \\
\hline Silicon-Aluminium, Si-Al & $\begin{array}{l}\text { Kaolinite, bentonite, and similar forms of } \\
\text { terra-cotta clay }\end{array}$ \\
\hline Iron, Fe & $\begin{array}{l}\text { Iron-based metals, including heated pyrite and } \\
\text { adulterated metallic minerals }\end{array}$ \\
\hline Silicon-Aluminium-Calcium, Si-Al-Ca & $\begin{array}{l}\text { Powdered blast furnace slag such as ashes } \\
\text { from fuel combustion ashes, oil-soluble }\end{array}$ \\
\hline Aluminium, Al & $\begin{array}{l}\text { Raw metallic apparatus constituting recycling } \\
\text { salt slag, aluminium hydroxide }\end{array}$ \\
\hline Sulphur, S & $\begin{array}{l}\text { Non-artificial gypsum such as Natural } \\
\text { anhydrite Gypsum from flue gas } \\
\text { desulfurization }\end{array}$ \\
\hline
\end{tabular}

Global cement generation was 4.1Bnt in 2020 with a growth rate of $24 \%$ from its highest in 2010 [6], with China clearly leading as the world's largest cement producer, representing $59.31 \%$ of overall manufactured cement globally. Table 2 shows the global cement production, with China producing more than $\frac{1}{2}$ of the world's cement combined. These recent expansions have been driven by developing countries such as India and China, with a substantial increase in cement manufacturing around Asia, Africa, and South America. As the earth's population and industrialization boom, universal cement production is bound to surge by at least $12-23 \%$ by 2050 [7]. Nigeria possesses the largest cement industry within West Africa, with at least 12 registered companies amounting to a merged cement capacity of $58.9 \mathrm{Mt} / \mathrm{yr}$. Dangote Cement is the largest cement producer in Nigeria and West Africa, manufacturing a combined share of more than $28.5 \mathrm{Mt} / \mathrm{yr}$ of cement capacity. Also, LafargeHolcim (through its subsidiary AshakaCem \& Lafarge WAPCO) and BUA Group boost $18.9 \mathrm{Mt} / \mathrm{yr}$ and $11.5 \mathrm{Mt} / \mathrm{yr}$ of integrated cement capacity, respectively [8]. With the increasing presence of cement manufacturing, the industry poses as one of the most significant $\mathrm{CO}_{2}$ emitters. Evaluating the risk factors of its spillover impact on public health is inevitable.

In Nigeria, limestone and marble are the main minerals of cement production. The conversion of this limestone into cement by heat releases carbon dioxide as a waste product. Ndefo [9] highlighted the deposits of these minerals and their carbon contents in various percentages, as shown in Figure 1. They are mainly composed of the carbonates of calcium and magnesium. Large deposits of calcium carbonate $\left(\mathrm{CaCO}_{3}\right)$ are observed in Calabar, Yandev, and Ukpilla, with Ewekoro having the largest deposit of Magnesium carbonate $\mathrm{MgCO}$. The Nigerian Ministry of Mines and Steel Development reports a total limestone collection of approximately 2.3 TMT, of which 568 MMT stands as proven reserve and 
11 MMT is used. Such deposits are endowed unadulterated, mainly across Ebonyi, CrossRiver, and Benue cities with large industrial volumes among Gombe, Edo, Sokoto, and Ogun. Nonetheless, the largest enriched West African nation is Nigeria.

Table 2. Global cement production in selected countries (in metric tonnes) [6].

\begin{tabular}{lcc}
\hline Countries & $\mathbf{2 0 1 8}$ & $\mathbf{2 0 1 9}$ \\
\hline United States & 87,000 & 89,000 \\
Brazil & 53,000 & 55,000 \\
China & $2,200,000$ & $2,200,000$ \\
Egypt & 81,200 & 76,000 \\
India & 300,000 & 320,000 \\
Indonesia & 75,200 & 74,000 \\
Iran & 58,000 & 60,000 \\
Japan & 55,300 & 54,000 \\
Korea, Republic of & 57,500 & 55,000 \\
Russia & 53,700 & 57,000 \\
Turkey & 72,500 & 51,000 \\
Vietnam & 90,200 & 95,000 \\
Other Countries & 870,000 & 900,000 \\
\hline
\end{tabular}

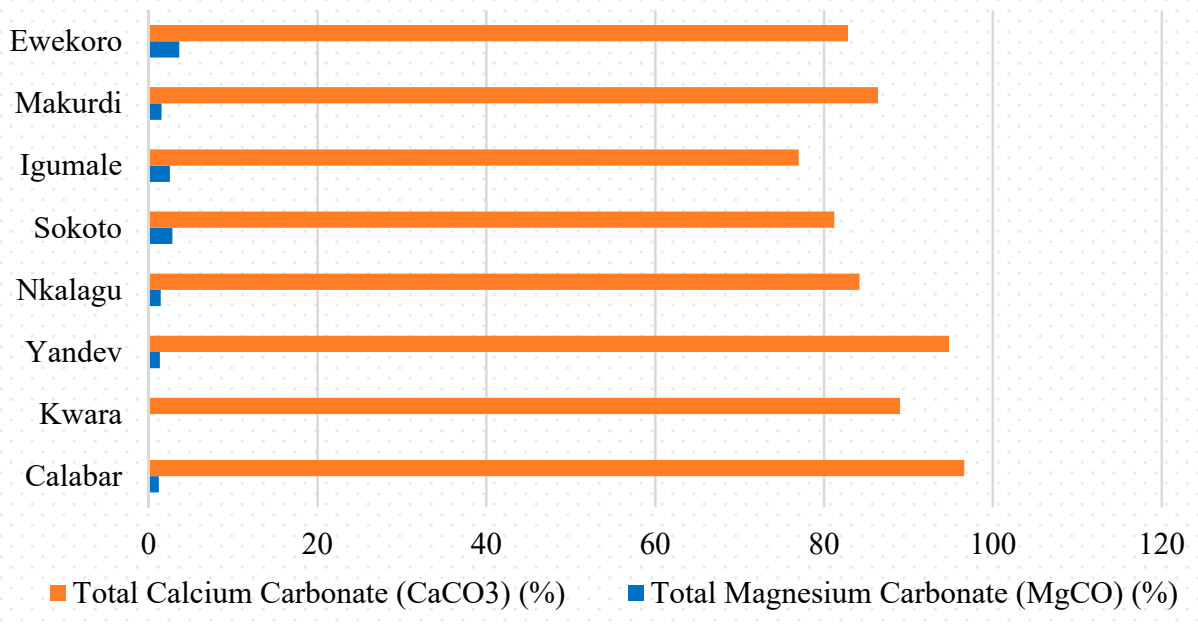

Figure 1. Percentage quantity of calcium carbonate and magnesium carbonate in Nigerian Limestone Deposit $[9,10]$.

In 2018, data from World Health Organization (WHO) indicated that 9 in 10 persons breathe air containing excessive concentrations of toxins beyond the approved threshold stated by WHO. Africa and Asia amass the worst hit with $90 \%$ deaths from environmental air contaminants [11]. During cement production, soot molecules and dusty residues emerge extensively, thereby triggering respiratory ailments across humans. Diverse pulmonic-connected diseases are prevalent mostly to indigenous persons living around cement industries. One cement factory releases massive atmospheric pollution. Given the voluminous process of producing cement, any certain potential environmental impact would be significant. As such, key players must prioritize atmospheric safety and decontamination since this undeniably plays an important role in achieving sustainable development (SDGs) goals 3, 6, 7, 11, 12 and 13 .

Higher cement production and usage, switching fuel types, and dirt restriction mechanization influence the quantity and cluster of environmental impurities. Numerous investigations admit that manufacturing cement constitutes the broadest source for PM emission, accounting for 20-30\%, which is $40 \%$ of the gross industrial emission [12]. Furthermore, making cement represents $5-6 \%$ of total artificial $\mathrm{CO}_{2}$ discharge, which according 
to the European Cement Association (ECA), yields at least half a ton of $\mathrm{CO}_{2}$ for a ton of cement produced. The most common pollutants responsible for air pollution are volatile organic compounds (VOCs), carbon monoxide (CO), particulate matter (PM), sulfur dioxide $\left(\mathrm{SO}_{2}\right)$, nitrogen oxides (NOx), and hydrocarbons [13]. Decarbonation propels off about $50 \%$ of the emission, while fuel for kiln firing induces approximately $40 \%$ of pollutants. With projected manufacturing spike, cement makers are under pressure to lower or sustain $\mathrm{CO}_{2}$ outflows. Carbon-neutral biomass amidst other substitute fuels is seeing heightened usage in reducing certain cement-based $\mathrm{CO}_{2}$ discharge. Cement manufacturing entails severe health constraints; nearly every production phase adversely affects man and its environment. When dismantling rocks, particulate matter is dispersed into the atmosphere, making it harmful to man. Moreover, this disintegration process causes noise pollution. The urban geography might likewise impact the gadgets adopted during this procedure [12,13]. Diverse equipment is recently employed to mitigate these adverse shortcomings. The equipment helps to limit dusty release, particularly across cement industries. Gas trappers similarly capture extreme toxins, including sulphur, nitrogen oxide, and carbon dioxide, among others [11,13]. An essential constituent of gas for cement production is carbon dioxide $\left(\mathrm{CO}_{2}\right)$. Heating calcium carbonate as the main ingredient produces lime, whereas carbon dioxide is given off as a chemical procedure. Cement production contributes $40 \%$ of global $\mathrm{CO}_{2}$ discharge; $60 \%$ of this $\mathrm{CO}_{2}$ volume comes from Portland cement [14,15], transforming limestone to lime. Sometimes, weighty metallic minerals spanning across mercury, chromium, thallium, and zinc have proximity to cement factories.

\section{The Growing Nigerian Cement Industry}

In recent years, the Nigerian cement industry has grown from import-dependency to an export-thriving epicentre within Africa. Cement is still a critical part of developing infrastructures globally as Nigerian cement producers continuously ramp up activities and expand into futuristic times. Given growing demands on infrastructural development, the National Integrated Infrastructure Master Plan (NIIMP) has projected a cumulative investment of approximately $\$ 3$ trillion for a duration of 3 decades to construct and sustain infrastructures. The Ministry for Mines and Steel Development [16] estimates Nigeria's highway system to be at $193,200 \mathrm{~km}$, whereby $28,980 \mathrm{~km}$ is paved and about $85 \%$ is unpaved. This fact highlights the tremendous pressure on cement manufacturers in meeting the country's demand for infrastructural development. Environmental health risks are of significant concern with the absence of a greener and more sustainable cement production in Nigeria. Juxtaposing the high degree of deficiency across the residential and structural facilities, particularly regarding the dire need for building properties and roadways, the capacity for expansion in this sector is evidently captivating. Additionally, the currently established amplitude has broadened to exceed projected demand as governmental strategies, including tax-relief schemes, banning imported cement, and similar enacted plans, have facilitated the rapid enlargement of capabilities for proprietary stakeholders [17]. In the medium term, Nigeria's concrete industry indicates a likelihood for considerably sustained growth into the next generation, supported by unimpaired cement demand essentials as revealed by multiple measurable benchmarks. Projections place Nigerian cement consumption per capita at about $150 \mathrm{~kg}$ falling behind the worldwide average of 561 $\mathrm{kg}$. Over the long term, several factors encompassing enhanced accessibility to construction funds, increased civilization, larger populace, heightened infrastructural and housing investment, political consistency, and economic affluence determine the possibilities for boosting cement demand in Africa's biggest country.

Besides other trivial functions of concrete for building, fascinations exist of using cement in constructing roads due to its resilience and easy preservation. More so, with the current population surge within Nigeria, it is believed that the government and increasing private sector will invest more in furnishing houses for bustling youths and working-class people, particularly inside and at the borders of urban cities. Consequently, to foster this movement, the federal government recently founded the Presidential Infrastructure De- 
velopment Fund (PFID) in 2018, overseen by the Nigeria Sovereign Investment Authority (NSIA), whose goal is to narrow down the investment to electricity and road schemes nationwide. Hence, cement demand growth in Nigeria is expected to increase local cement production over the following years. Nigeria's cement sector exhibits oligopolistic tendencies with three major competitors as presented in Figure 2. Dangote Cement Plc, the indisputable biggest producer in Sub-Sahara and Nigeria with an installed capacity of 48.6 Mta and 32.3 Mta respectively, just recently added 3 million tonnes to its capacity in 2020 in the Obajana Cement Plant. Lafarge Africa Plc has a capacity of 10.5 million metric tonnes, accounting for a market share of $21.8 \%$. BUA Group (recently sealed a merger of $\mathrm{CCNN}$ and $\mathrm{Obu}$ ) has an 8.0 million metric tonnes capacity, accounting for a market share of $17.6 \%$. Regardless of the current capabilities, the key manufacturing industrial giants are relentless in diversification strategies. According to their media sources, Dangote Cement has hinted at developing two extra 6MTPA factories in Edo city's Okpella and Ogun state's Itori. Additionally, BUA Group (CCNN) intends to extend its Sokoto's Kalambaina Plant by supplementary 3MMTA. These plants are generally sited close to the raw material to cut the cost of transporting them. With limestone in its abundance, cement production in Nigeria is at its infant stage. Dangote cement further observes that Obajana's accumulated limestone of 647 MT should stretch for approximately 45 years, Ibese's 1150 MT should cover 78 years, and Gboko's 133 MT should surpass three decades.

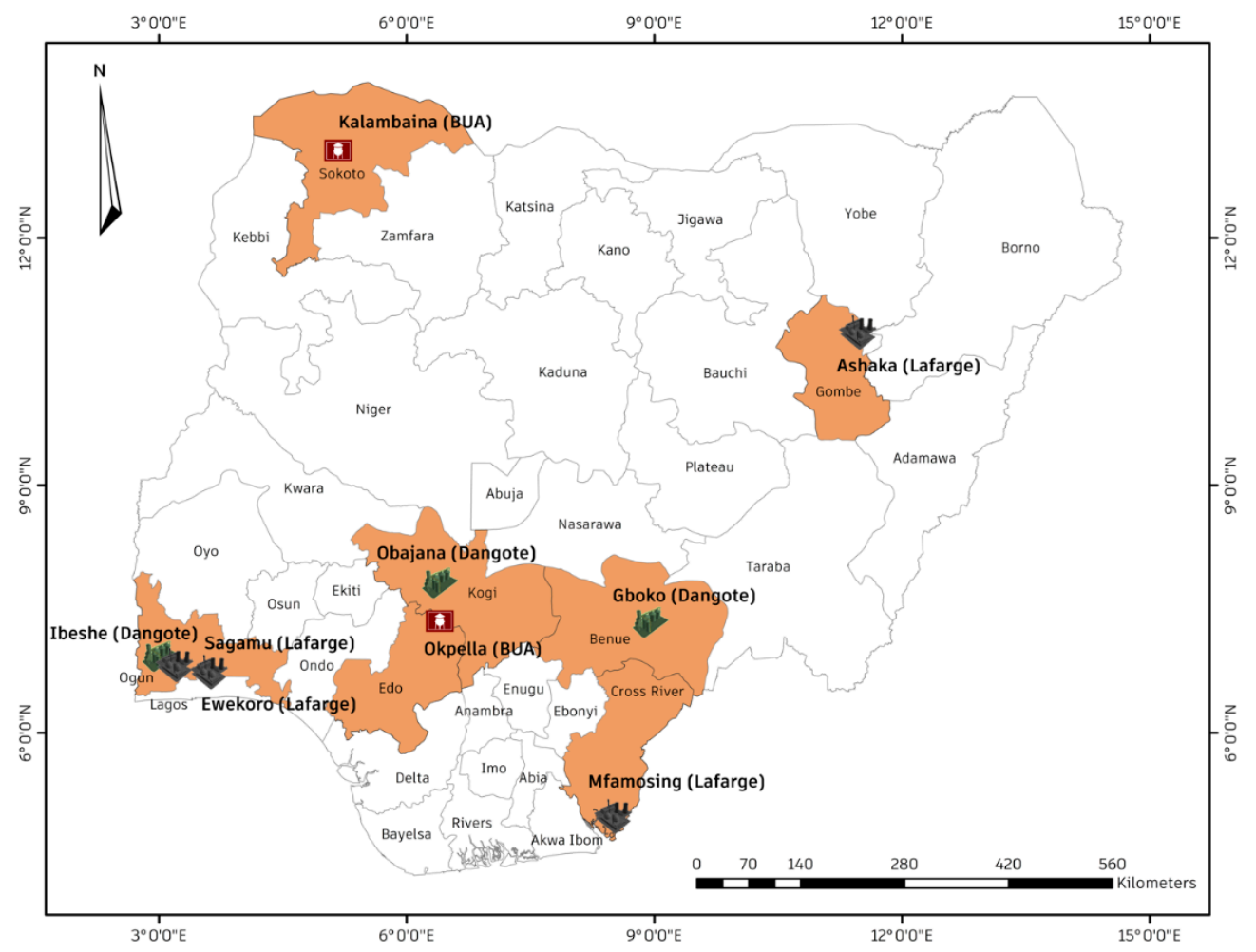

Figure 2. Major Cement Plants in Nigeria.

Over time, Nigerian cement manufacturers have used domestic cinder and proxy combustibles such as LPFO (Low Pour Fuel Oil-a byproduct of petroleum oil) as an alternative to gas in powering their plants. Dangote Cement, for instance, has tactically reinforced its limekilns to function better with coals. This encompasses Ibese and Obajana industries, which were formerly structured to operate on gas, whereas Benue's factory previously used LPFO. Dangote group also indicated tendencies to utilize its numerous damaged tyres as energy sources. Similarly, Lafarge Africa Plc has heightened its usage of substitute power, including coal and industrial waste. 


\section{Cement Production on Climate Change and Global Warming}

As highlighted by USGS, global warming is one of many characteristics of climate change. Global warming is the rise in global temperatures largely due to escalating concentrations of atmospheric greenhouse gases. Similarly, climate change involves the gradual alteration of climatic actions for an extended period [18]. Increased urbanization and industrialization have led to higher cement production in Nigeria as cement plants have substantially ramped up their output, triggering greater $\mathrm{CO}_{2}$ emissions into the air. Ndefo [9] highlighted that using the ratio of one cement to carbon dioxide tonne, Nigeria would manufacture beyond 25 MMT of cement, thereby inducing 25 MMT of $\mathrm{CO}_{2}$ yearly. This has eventually drawn the country into global warming and weather crisis. Developing nations like Nigeria lack sufficient preparation for global warming consequences, which is already evident and glaring for its citizens. Notwithstanding that Africa's largest country has fortunately not encountered severe atmospheric-spurred disaster, occurrences are constantly seen in tremendous heat waves around major industrial cities; increased greenhouse gases and particulate matter; PMs from cement dust pollution; and high precipitations leading to flooding and gully erosion [14] in Lagos, Jigawa, Edo, and Anambra States. The atmospheric $\mathrm{CO}_{2}$ before industrialization was about $200 \mathrm{ppm}$, but it is presently estimated to surpass $800 \mathrm{ppm}$ as the 21st century reaches its end, causing great concerns. The cement sector is a principal contributor to weather disruptions because its manufacturing operations emit enormous $\mathrm{CO}_{2}$, which is primarily unrecoverable and reusable [19,20]. Wilson \& Law (2007) [21] further describe cement production as a greenhouse double whammy, by which the conversion of limestone to cement produces carbon dioxide; the fossil fuel used in heating it also produces carbon dioxide. In 2019, Netherlands Environmental Assessment Agency reported the increase in earthly $\mathrm{CO}_{2}$ discharge by a projected $350 \mathrm{MtCO} 2$ or $0.9 \%$ to reach $38 \mathrm{GtCO}_{2}$, such that China incurs the highest contribution with an increased $3.4 \%$ (or $380 \mathrm{MtCO}_{2}$ ) and Nigeria's emission at approximately $100 \mathrm{MtCO}_{2}$ [22]. Table 3 highlights the atmospheric emissions from 1970 to 2019 in Nigeria. Cement manufacturing is estimated to supply $5-10 \%$ of worldwide anthropogenic $\mathrm{CO}_{2}$ outflow [23]. However, about $40 \%$ of $\mathrm{CO}_{2}$ emissions from dry cement manufacturing come from the combustion of fossil fuels [24] in the kiln process, while 50\% comes from the roasting of limestone. The roasting (calcination) process liberates $\mathrm{CO}_{2}$ from limestone to give quick-lime: an essential resource in making cement clinkers. The process is energy-intensive and with extreme temperatures of about $1450{ }^{\circ} \mathrm{C}$ [25].

Table 3. Atmospheric emissions from 1970 to 2019 in Nigeria.

\begin{tabular}{ccccc}
\hline Years & $\begin{array}{c}\text { Carbon Dioxide }\left(\mathrm{CO}_{2}\right) \\
\text { Emission }\end{array}$ & $\begin{array}{c}\text { Methane }\left(\mathrm{CH}_{4}\right) \\
\text { Emission }\end{array}$ & $\begin{array}{c}\text { Nitrous Oxide, }\left(\mathbf{N}_{\mathbf{2}} \mathbf{O}\right) \\
\text { Emission }\end{array}$ & $\begin{array}{c}\text { Greenhouse Gases (F-Gases): } \\
\text { (HFCs, PFCs and SF6) Emission }\end{array}$ \\
\hline 1970 & 0.03 & 130 & 12 & - \\
\hline 1971 & 0.04 & 190 & 12 & - \\
\hline 1972 & 0.06 & 230 & 12 & - \\
\hline 1973 & 0.07 & 280 & 13 & - \\
\hline 1974 & 0.08 & 350 & 14 & - \\
\hline 1975 & 0.06 & 260 & 14 & - \\
\hline 1976 & 0.08 & 290 & 14 & - \\
\hline 1977 & 0.07 & 250 & 15 & - \\
\hline 1978 & 0.07 & 240 & 15 & - \\
\hline 1979 & 0.10 & 370 & 16 & - \\
\hline 1980 & 0.09 & 310 & & - \\
\hline
\end{tabular}


Table 3. Cont.

\begin{tabular}{|c|c|c|c|c|}
\hline Years & $\begin{array}{l}\text { Carbon Dioxide }\left(\mathrm{CO}_{2}\right) \\
\text { Emission }\end{array}$ & $\begin{array}{l}\text { Methane }\left(\mathrm{CH}_{4}\right) \\
\text { Emission }\end{array}$ & $\begin{array}{l}\text { Nitrous Oxide, }\left(\mathrm{N}_{2} \mathrm{O}\right) \\
\text { Emission }\end{array}$ & $\begin{array}{l}\text { Greenhouse Gases (F-Gases): } \\
\text { (HFCs, PFCs and SF6) Emission }\end{array}$ \\
\hline 1981 & 0.07 & 230 & 16 & 0.1 \\
\hline 1982 & 0.07 & 200 & 17 & 0.1 \\
\hline 1983 & 0.07 & 200 & 17 & 0.1 \\
\hline 1984 & 0.07 & 210 & 17 & 0.1 \\
\hline 1985 & 0.07 & 220 & 18 & 0.1 \\
\hline 1986 & 0.07 & 220 & 18 & 0.1 \\
\hline 1987 & 0.07 & 200 & 18 & 0.1 \\
\hline 1988 & 0.08 & 230 & 19 & 0.2 \\
\hline 1989 & 0.08 & 240 & 19 & 0.2 \\
\hline 1990 & 0.07 & 240 & 19 & 0.2 \\
\hline 1991 & 0.08 & 250 & 20 & 0.2 \\
\hline 1992 & 0.09 & 250 & 20 & 0.1 \\
\hline 1993 & 0.09 & 260 & 21 & 0.1 \\
\hline 1994 & 0.08 & 250 & 21 & 0.1 \\
\hline 1995 & 0.09 & 260 & 22 & - \\
\hline 1996 & 0.10 & 280 & 22 & 0.1 \\
\hline 1997 & 0.10 & 250 & 23 & 0.1 \\
\hline 1998 & 0.09 & 210 & 24 & 0.2 \\
\hline 1999 & 0.09 & 190 & 24 & 0.2 \\
\hline 2000 & 0.10 & 190 & 25 & 0.3 \\
\hline 2001 & 0.11 & 200 & 25 & 0.3 \\
\hline 2002 & 0.10 & 170 & 26 & 0.4 \\
\hline 2003 & 0.11 & 190 & 26 & 0.5 \\
\hline 2004 & 0.10 & 190 & 26 & 0.6 \\
\hline 2005 & 0.10 & 190 & 29 & 0.7 \\
\hline 2006 & 0.09 & 180 & 28 & 0.8 \\
\hline 2007 & 0.08 & 180 & 28 & 0.8 \\
\hline 2008 & 0.09 & 170 & 29 & 0.9 \\
\hline 2009 & 0.08 & 170 & 29 & 1.0 \\
\hline 2010 & 0.09 & 180 & 30 & 1.1 \\
\hline 2011 & 0.10 & 180 & 32 & 1.2 \\
\hline 2012 & 0.09 & 190 & 32 & 1.3 \\
\hline 2013 & 0.09 & 180 & 32 & 1.3 \\
\hline 2014 & 0.09 & 180 & 32 & 1.4 \\
\hline 2015 & 0.09 & 180 & 34 & 1.5 \\
\hline 2016 & 0.09 & 180 & 35 & 1.6 \\
\hline 2017 & 0.09 & 180 & 36 & 1.7 \\
\hline 2018 & 0.10 & 180 & 37 & 1.7 \\
\hline 2019 & 0.10 & 180 & 38 & 1.8 \\
\hline
\end{tabular}

Unit $=10^{9} \mathrm{~kg} \mathrm{CO}_{2}$ eq (1 million metric tonnes). $\mathrm{CO}_{2}$ equivalent is calculated with Global Warming Potentials (GWP-100) of the Fourth IPCC Assessment report (2017). Graphical illustration in Supplementary Data. 
Globally, increasing industrialization has led to a rise in carbon dioxide levels in the atmosphere to about $0.03 \%$ (570 ppm) [26]. To maintain the $\mathrm{CO}_{2}$ concentration below 550 ppm by 2050, Cement Technology Roadmap has recommended cutting $\mathrm{CO}_{2}$ emissions to $30-60 \%$, thereby mitigating global warming [27]. Cement plants are a major source of $\mathrm{CO}_{2}$ emissions due to the high $\mathrm{CO}_{2}$ concentration in cement kiln flue gas [26]. However, with the advent of carbon capture and storage (CCS), cement manufacturers have discovered a system of reducing the role of fossil fuel emissions in global warming by capturing and storing $\mathrm{CO}_{2}$ directly from the atmosphere [28]. Together with the underground gasification combined cycle (UGCC), CCS is a viable method for exploiting clean limestone and coal [29]. Techniques of pre-combustion capture, post-combustion capture, and oxy-fuel combustion are widely used for carbon dioxide capturing in the cement industry [30].

The manufacturing sector and agricultural sector have contributed significantly to the Nigerian Gross National Product. The active role of these sectors makes it evident that even a minor climate deterioration can cause harmful socioeconomic consequences. In the cement industry, policies to reduce the combustion of fossil fuels like carbon and to adopt renewable energy sources have only been successful at the paper stage as there is poor or no acceptance of these methods. Nigeria is the biggest cement manufacturer across West Africa, with increasing production demands. Its cement production utilizes a large volume of unprocessed input and combustibles (biodiesel, crude oil, gasoline, coal, among other factory wastage) and thermal and electrical power for its production [31-33], playing a major role in environmental variations and global warming as a result of its raw material use and processing [34]. Although cement production causes noise pollution, which is detrimental to man's health, the main environmental issue associated with its production is the formation of heavy metals as seen in wastewater and solid waste such as carbon-dioxide $\left(\mathrm{CO}_{2}\right)$ emission, VOCs, fly ash, dust, and particulate matters (PMs) [31]. Sadly, solutions for the climate change and global warming challenges do not yield intense renowned impact since they are far too complex for political discussions. The looming effects of climate variabilities now threaten stable food supply in some regions of the country. In the arid zones of northern Nigeria, droughts are getting worse, and the southern part is getting wetter with growing climate uncertainty. A major influence of weather changes and global warming is weather unpredictability. This is so conspicuous as some areas in Lagos and Ogun State were said to have experienced an uncommon rainfall with thunderstorms in the early days of 2021, drawing attention to the fact that these regions record the highest number of industries in Nigeria. The challenge of climate unpredictability makes subsistence farming difficult [14]. Research has shown that the leading cause of environmental disruptions is the continuously rising $\mathrm{CO}_{2}$ levels from emitting biomass, concrete production, and desertification, which are the major causes of $\mathrm{CO}_{2}$. As of 2020, the current trend of $\mathrm{CO}_{2}$ emission in Nigeria from cement production is still on the rise. As presented in Figure 3, carbon-dioxide $\left(\mathrm{CO}_{2}\right)$ emissions in Nigeria have been growing steadily from 1970 to date. The earth's $\mathrm{CO}_{2}$ level will keep escalating owing to high demand for concrete (cement production), incessantly combusting fossil fuels, land-use adaptations, and particularly deforestation. 


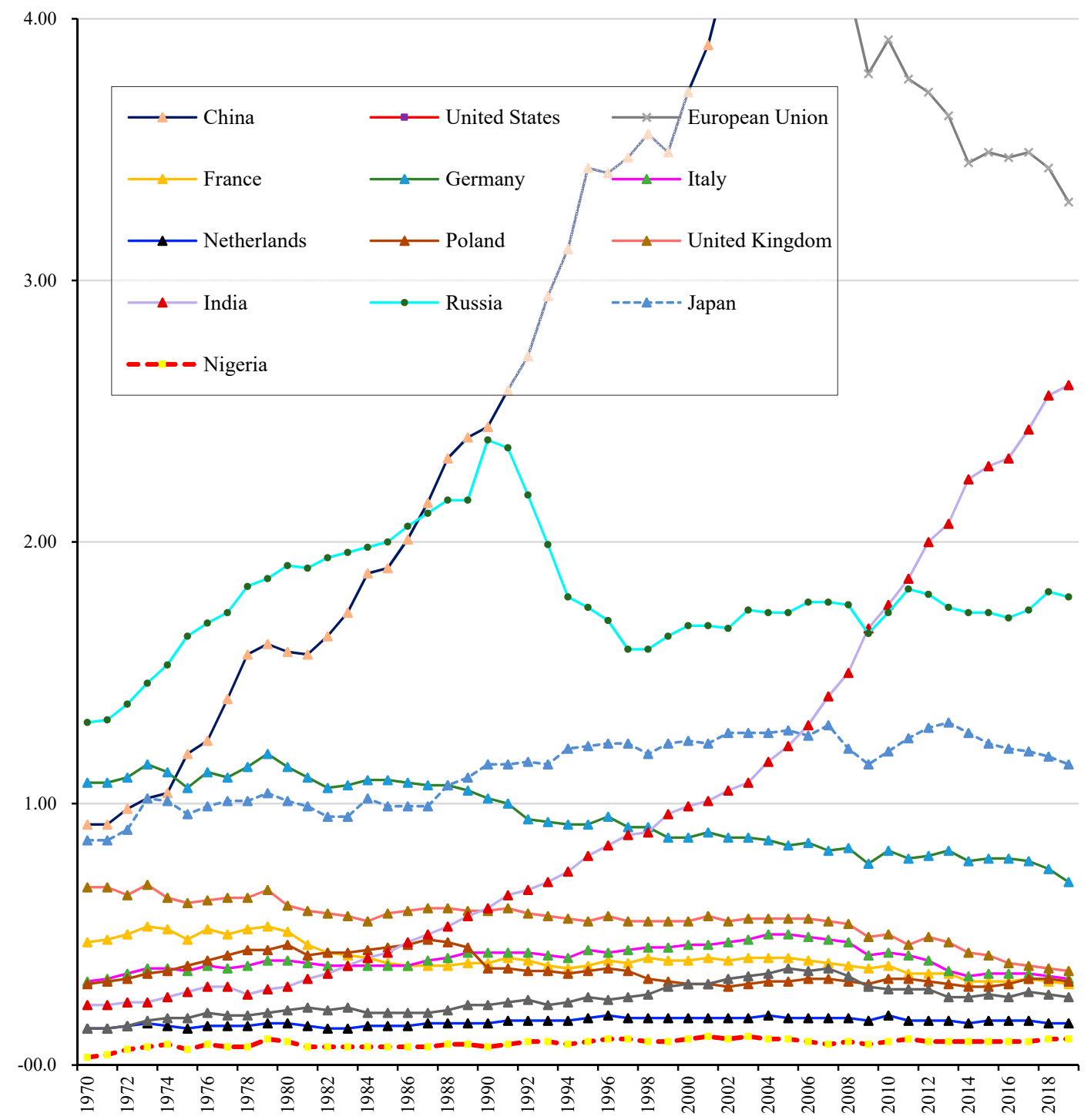

Figure 3. Carbon-dioxide $\left(\mathrm{CO}_{2}\right)$ emissions from 1970 to 2019 in Nigeria and other countries.

\section{Impacts of Water Pollution from Cement Production on Public Health}

Anthropogenic activities have depleted the quality of human's most abundant resources. Water contamination through industrialization and urbanization in Nigeria is leading the cause of water-related conundrums [35,36]. Globally, uncontaminated drinkable water is inaccessible to billion(s) of persons [37], leading to 2.2 million deaths yearly in developing nations [38]. Nigeria is naturally endowed in abundance with diverse categories of drinking water such as groundwater, rainwater, and surface water, but it has a longstanding challenge in water quality problems [39]. Approximately 66.3 million Nigerians lack access to clean drinking water, which is largely attributed to the pollution from cement production [40], oil exploration [41], agricultural activities [42], and industrial or mining activities [43], etc. Water contamination through cement production in Nigeria has facilitated toxins accumulation in aquatic lives, causing a health risk to human consumers. In past years, the constant epidemic of water-borne diseases such as diarrhoea, dysentery, cholera, and gastroenteritis in Nigeria has been linked to polluted water [36]. Cement industries are largely responsible for releasing effluents into water bodies [24,44,45]. In a study by [46], clear water quality deterioration was discovered in Oinyi river, Kogi State, owing to cement factories' unhygienic water effects. Collected analyzed samples along the watercourse highlighted the following results: turbidity, temperature, biochemical and 
chemical oxygen demand, colour, $\mathrm{pH}$, depth, conductivity, and total suspended solids as 14-22.7 NTU, $24^{\circ} \mathrm{C}$ to $27^{\circ} \mathrm{C}, 2.05-2.89 \mathrm{mg} / \mathrm{L}, 17.19 \pm 0.15 \mathrm{mg} / \mathrm{L}, 3.87 \pm 0.159$ Pt.Co, 6.8 to $7.26,0.23$ to $0.35 \mathrm{~m}, 106.0$ to $211.7 \mu \mathrm{S} / \mathrm{cm}, 45-54 \mathrm{mg} / \mathrm{L}$, respectively, but at the exit point of the industrial effluents; turbidity, nitrite, nitrate, maximum conductivity, total dissolved solids, and total suspended solids are $22.7 \mathrm{NTU}, 0.09 \mathrm{mg} / \mathrm{L}, 0.006 \mathrm{mg} / \mathrm{L}, 211.7 \mu \mathrm{S} / \mathrm{cm}$, $108.8 \mathrm{mg} / \mathrm{L}$, and $54 \mathrm{mg} / \mathrm{L}$ respectively [46].

\section{Impacts of Air Pollution from Cement Production on Public Health}

Cement factories and limestone-induced atmospheric pollution are seen to evoke severe occupational health hazards and adverse effects on crops, buildings, and persons residing in the vicinity of these industries [47]. Producing concrete consumes enormous power, often through coal, which consequently emits carbon dioxide in alarming amounts depending on the manufacturing procedure and fuel employed as well as its associated effectiveness. The highly critical aftermath of producing cement is the dirt emitted during mining, processing, packaging, storing, and transporting. Egbe et al. (2019); Ibanga et al. (2008); and Maina et al. (2013) [48-50] highlighted that products and raw materials from cement production plants are significant sources of particulate matter such as (PM), NOx, $\mathrm{CO}_{2}, \mathrm{SO}_{2}$, VOCs, Ozone $\left(\mathrm{O}_{3}\right)$, hydrogen sulphide $\left(\mathrm{H}_{2} \mathrm{~S}\right)$, polychlorinated dibenzo-p-dioxins (PCDDs), polychlorinated biphenyls (PCBs), polychlorinated dibenzofurans (PCDFs), and highly radioactive elements like Radon. Carbon monoxide (CO) and hydrocarbons obtained from incomplete conflagration [1] in the kiln cause perilous healthy impacts by lessening oxygen transmission to bodily parts and ligaments, in addition to negatively impacting brainwaves and cardiorespiratory conditions. Furthermore, $\mathrm{CO}$ aids fume generation (bottom-ground ozone), which triggers breathing difficulties [13,51]. Nitrogen oxide (NOx) released during fuel combustion causes multiple health-related challenges. It adversely affects the atmosphere through global warming, visual impairment, acid rain, lung disease such as asthma, and lung tissue damage [13,52]. Sulfur dioxide $\left(\mathrm{SO}_{2}\right)$ from fuel sources and the type of raw materials used in cement production could complicate respiration and exacerbate prevailing lung and health-associated ailments. Moreover, the kiln type used in concrete production influences the volume of $\mathrm{SO}_{2}$ that enters the air [53]. Emitted $\mathrm{SO}_{2}$ is oxidised into $\mathrm{SO}_{3}$ in the atmosphere, forming sulfate aerosols or acid deposition on surface soil and water [54]. Radon ( $\mathrm{Rn})$, a radioactive gas derived from geologic materials, has been linked to an increased risk of developing lung cancer when inhaled in large quantities from concrete or cement [55]. Cement production at various stages is accompanied by the release of dust [56]. Particulate matter (PM) discharged from concrete industries lie between 0.025 to $5 \mu \mathrm{m}$ in radius [48,57]. Particle sizes of particulate matter play a role in its effects [58]. PM2.5 is responsible for several people's wellness shortcomings relative to other PM dimensions [59]. Sizes within 10 to $2.5 \mu \mathrm{m}$ enter the higher region of respiratory organs, whereas lower PM sinks into the blood and lungs. World Bank noted in 2015 that $94 \%$ of Nigeria's populace is vulnerable to environmental contamination levels that outpace the WHO threshold [60]. It was further reported in 2017 that the volume of immature deaths owing to Nigerian atmospheric $\mathrm{PM}_{2.5}$ stood at 49,100 , and children below 5 have the greatest susceptibility, mainly because of lesser respiratory contagion, representing approximately $60 \%$ of overall $\mathrm{PM}_{2.5}$-induced deaths [61]. Globally, subjection to environmental dust $\mathrm{PM}_{2.5}$ has caused around 2.9 million premature deaths, $9 \%$ of aggregate deaths worldwide and 80,000 premature deaths in West Africa for 2017 [61]. This issue is worse within Nigeria, with the largest regional mass of $\mathrm{PM}_{2.5}$-associated deaths, especially in Lagos, the nation's industrial hub. From Figure 4, the assessment of $\mathrm{PM}_{2.5}$ in Lagos at $68 \mu \mathrm{g} / \mathrm{m}^{3}$ exceeds the World Health Organization's benchmark for the concentration of $10 \mu \mathrm{g} / \mathrm{m}^{3}$, placing Nigeria's industrial capital closely among the most polluted cities. Figure 5 illustrates the state of cement production in Nigeria. 


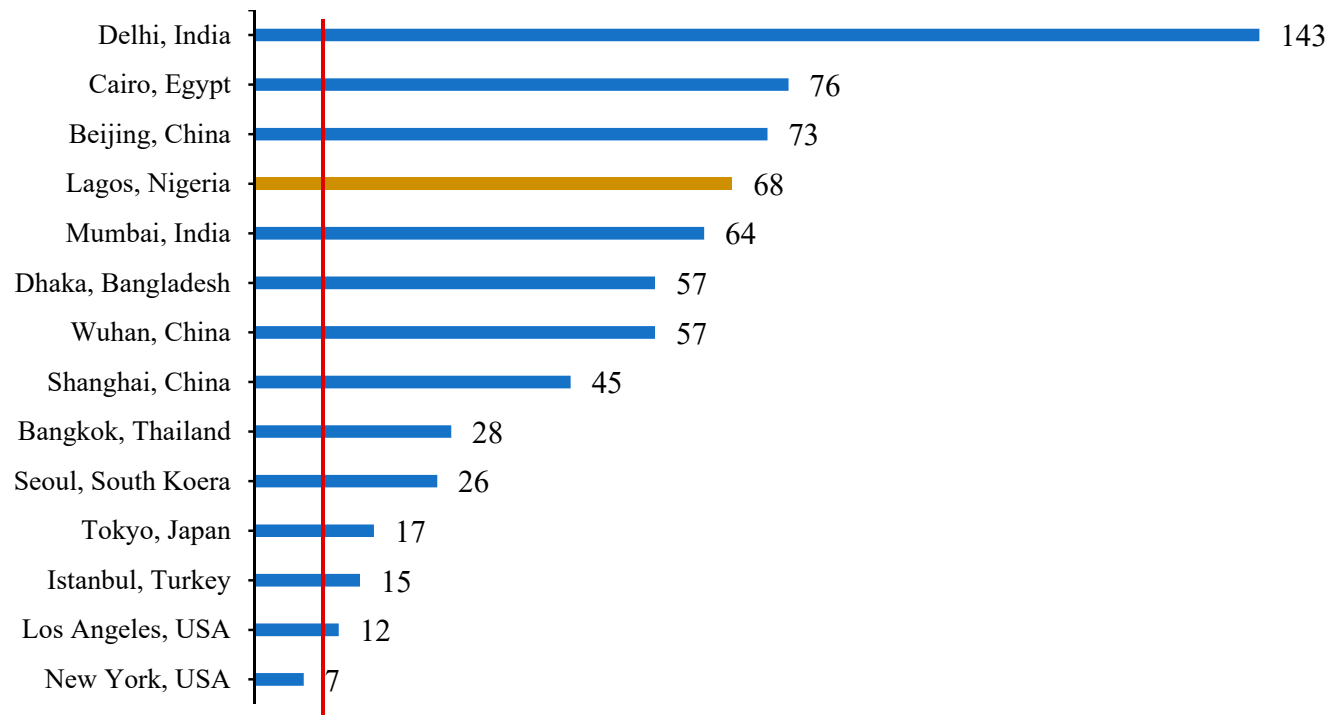

Figure 4. Annual mean concentration of $\mathrm{PM}_{2.5}\left(\mu \mathrm{g} / \mathrm{m}^{3}\right)$ in various cities [61].

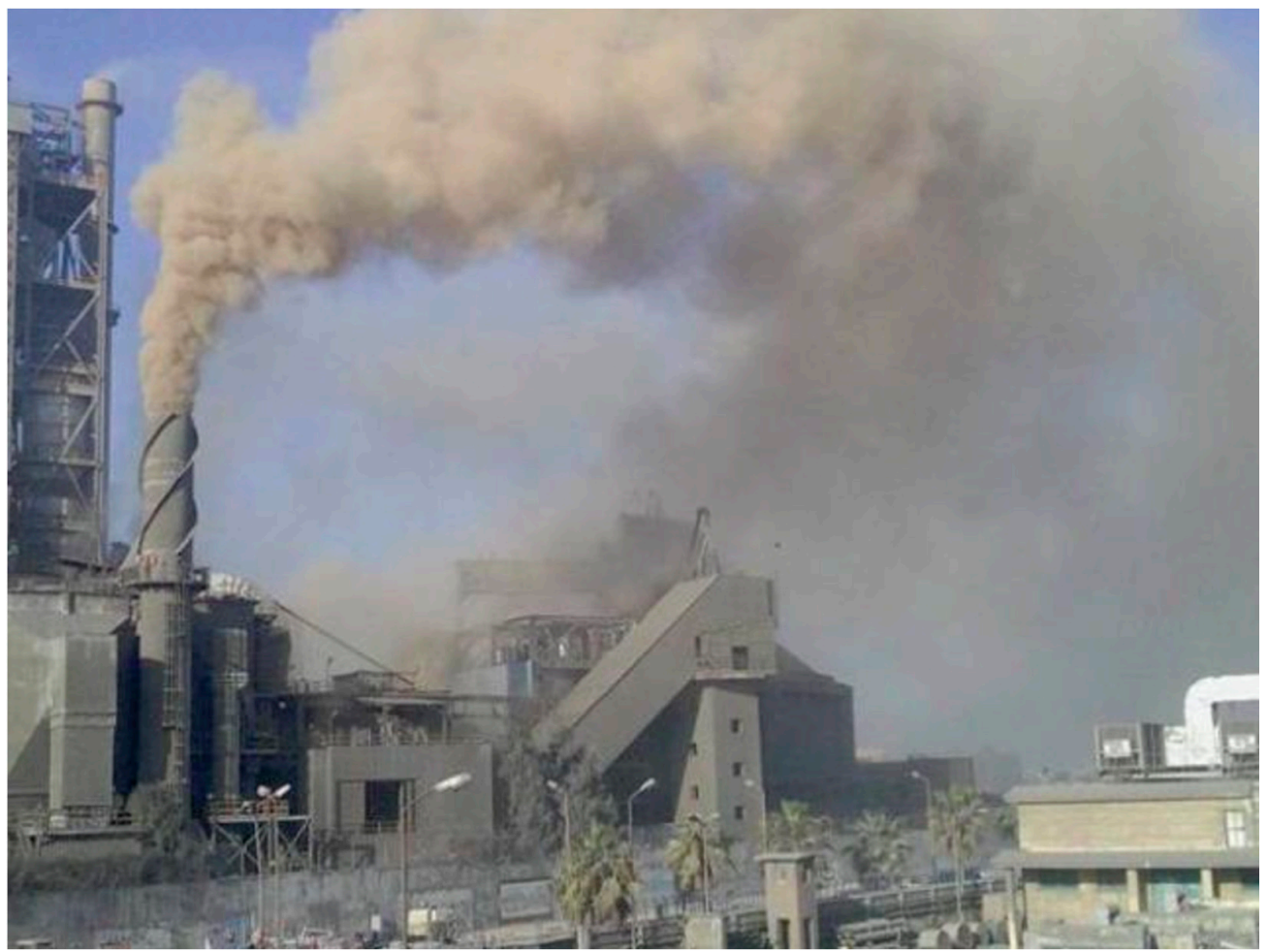

Figure 5. Pollution from cement production in Nigeria. Source: [62].

Abimbola et al. (2007) [63] evaluated past hospital documentations and the present well-being of locals and revealed the increasing contagion of sickness connected to huge alloy fatality, generated by cement dust from factories, posing a threat to future habitation. The research considered the quantities of selected heavy metals in Figure 6 as: soils [Ni (13.0-17 ppm), Cd (0.5-1.1 ppm), Zn (43-69 ppm), Cu (22-35 ppm), Pb (28-49 ppm)], shale [Cu (2.0-11 ppm), Pb (17-22 ppm), Cd (0.3-1.1 ppm), Ni (3.0-18 ppm), dusts [Cd (0.5-0.7 ppm), Zn (17-147 ppm)], Cu (2-16 ppm), Pb (32-52 ppm), Ni (2-17 ppm)], $\mathrm{Zn}(5-152 \mathrm{ppm})$, limestone [Cu (3.0-11 ppm), Ni (3.0-8.0 ppm), Cd (n.d.-1.7 ppm), $\mathrm{Zn}(7.0-53 \mathrm{ppm})$, and $\mathrm{Pb}(42-48 \mathrm{ppm})]$. 


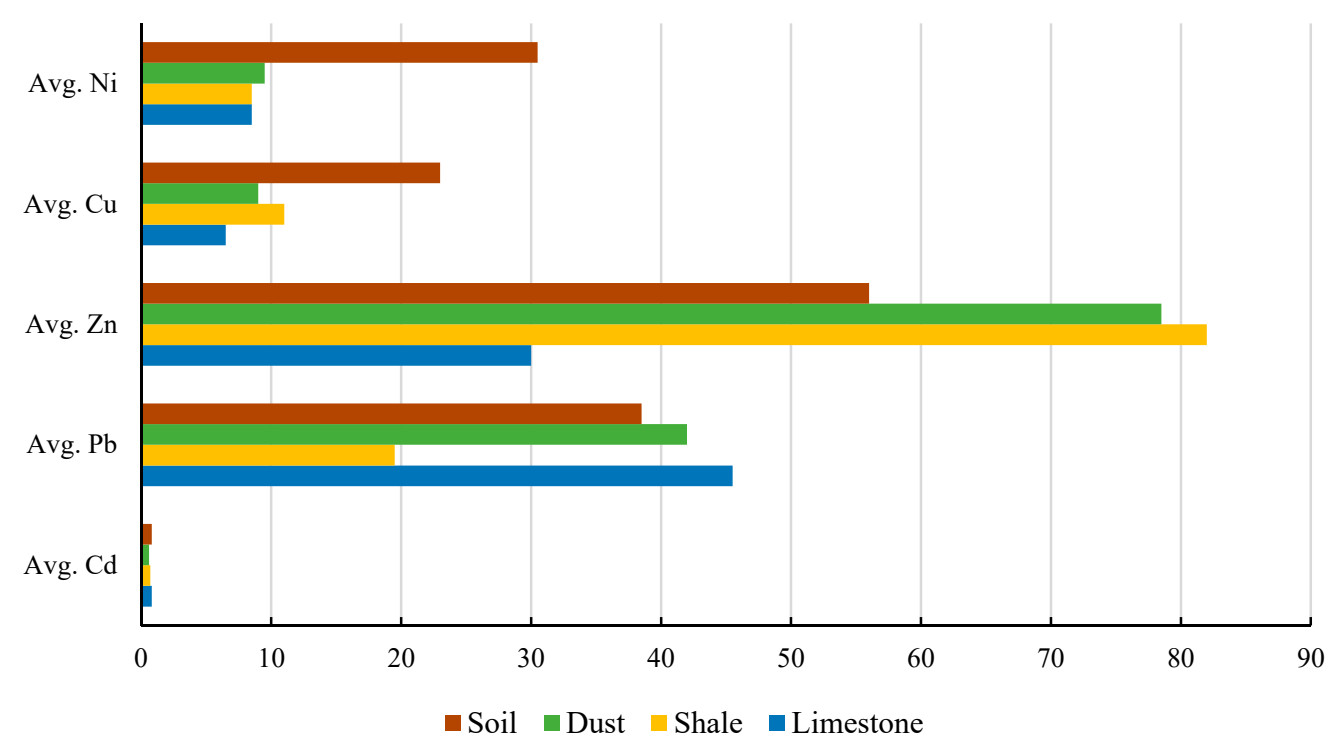

Figure 6. Average levels of heavy metals around Sagamu cement area (in ppm).

The study further proposed that the voluminous metallic concentration in the soil and soot emanated from unprocessed inputs adopted by cement makers and resultant factory emissions. A study performed by A. N. (2012) [64] revealed that 30,435 disease cases were linked to air pollution in Rivers State, and 61 of its patients were reported dead. Prevalent diseases associated with the cases include: cerebrospinal meningitis (CSM), pulmonary tuberculosis, upper respiratory tract infection (URT), pneumonia, measles, pertussis, and chronic bronchitis. The environmental air quality was also reported to be far worse than the WHO's standard, and unsafe, posing health threats to residents (particulates $=10 \mathrm{ppm} /$ year, $\mathrm{SO}_{2}=1 \mathrm{ppm} /$ year, $\mathrm{Pb}=0.1115 \mathrm{ppm} /$ year, $\mathrm{NOx}=2.55 \mathrm{ppm} /$ year, VOCx $=82.78 \mathrm{ppm} /$ year). This study implied that air pollution largely from industrial emission has negatively forthrightly impacted public welfare. The aftermath of Ewekoro's kiln impurities was closely observed by Olaleye \& Oluyemi (2010) [65] at some aquatic receptor places, and a considerable concentration of atmospheric deposition rates (ADRs) and total suspended particulates (TSPs) was observed in the cement plant. The TSP and ADR concentrations were significantly more $(p<0.05)$ amidst dryer weather compared to humid periods. Furthermore, in the study, airborne particulates contain substantially greater concentration $(p<0.05)$ of trace elements such as lead $\left(\mathrm{Pb}^{+}\right)$, zinc $\left(\mathrm{Zn}^{2+}\right)$, and manganese $\left(\mathrm{Mn}^{2+}\right)$. Similarly, Ugwuanyi \& Obi (2002) [66] examined the adverse health consequences of environmental contaminants from cement industries on small-scale peasants in Nigeria's Benue State. The research observed data from hospitals and correlated them with emissions from the vicinity of the plant. Diseases predominant amongst the community include allergic asthma allergies, impaired eyesight, chronic bronchitis, upper respiratory tract infection (URTI), lung inflammation, and pulmonic tuberculosis. He concluded that the measurable atmospheric effects of hospitalized persons relative to sicknesses suggest that pollutants have begun dampening living quality and people's productivities.

A.J. (2013) [67] observed that the particulate matter concentrations from Obajana cement plant measured by its Health and Safety Department using the SKC portable particulate sampler at several industry sites for years 2010 and 2011 were $260 \mu \mathrm{g} / \mathrm{Nm}^{3}$ and 500 $\mu \mathrm{g} / \mathrm{Nm}^{3}$, respectively. Furthermore, Ugwuanyi \& Obi (2002) [66] observed that suspended particulate matter at Benue Cement Company, Gboko was at $905 \mu \mathrm{g} / \mathrm{Nm}^{3}$, far exceeding both national and international standards. A study by Temitope \& Ogochukwu Elizabeth (2014) [68] discovered the contamination of hawked food around a cement factory with pathogenic bacteria. The study further revealed the presence of a high microbial load of bacterial pathogens, namely Salmonella sp., Shigella sp., Bacillus sp., Klebsiella sp., Escherichia coli, Pseudomonas sp., Proteus sp., Micrococcus sp., Staphylococcus sp., Streptococcus sp., 
Streptococcus pyogenes, etc. in hawked food sold around a cement factory in Lokoja. The high microbial load in the food ranges from $6.2-3.3 \times 10^{5} \mathrm{cfu} / \mathrm{g}$, showing the likelihood of incidence of these organisms dispersed by dust from the cement plant onto the hawked food. Other research has indicated the clustering of suspended PMs and nitrogen dioxide $\left(\mathrm{NO}_{2}\right)$ exceeding guidelines in stations around Cement depots in Port Harcourt. Using a collection of impingers possessing bubbler tools and automated gas monitors, the outcome of concentrated SPM for Atlas cement fluctuated within $678.9-996.2 \mu \mathrm{g} / \mathrm{m}^{3}$ and between 7.8-20.0 $\mu \mathrm{g} / \mathrm{m}^{3}$ for $\mathrm{NO}_{2}$. For Eagle cement, SPM concentrations were extremely varied between $607.7-23,198.5 \mu \mathrm{g} / \mathrm{m}^{3}$ and $27.45-140.7 \mu \mathrm{g} / \mathrm{m}^{3}$ for $\mathrm{NO}_{2}$. This gives rise to damaging environmental and serious public unhealthiness distress as concrete SPM toxins emanate from cement unpacking, transportation, storing, and stacking onto carriage vans [69]. Otaru et al. (2013) [70] indicated that the simulated safety distance for human settlement is $7 \mathrm{~km}$ from a cement production plant, having utilized the Gaussian predictive model to measure the levels of particulate dissemination. This has negatively affected the populace around a cement plant as they are forced into settlement migration for greener pasture. The simulated outcomes agreed with experimental results at an average value of $92 \%$ within a Gaussian distance of 200-2000 $\mathrm{m}$. These simulated findings reveal that the atmospheric cluster covering around $1.5-4.5 \mathrm{~km}$ from the heap exceeds the WHO yearly average yardstick of $260 \mu \mathrm{g} / \mathrm{m}^{3}$, and $2-4 \mathrm{~km}$ from the stockpile likewise surpassed the Nigerian Federal Ministry of Environmental criterion annual average of $500 \mathrm{\mu g} / \mathrm{m}^{3}$.

\section{Conclusions}

In conclusion, this work reviews the effect of air and water pollutants from cement production on humans, plants, and its environment. There is satisfactory evidence to link the negative health impact of cement production on public health. Cement manufacturing involves the significant production of $\mathrm{SO}_{2}, \mathrm{NOx}$, and $\mathrm{CO}$, which are connected to adverse health effects on humans. Sensitive populations such as infants, the aged, and persons having lung ailments including asthmatics, emphysema, or bronchitis, are seen to be most affected. Consequently, in addressing this challenge, growing interests in enacting carbon capture, usage, and storage in the cement industry are expected to alleviate the negative environmental impact of cement production. Still, no carbon capture technology is yet to achieve commercialization in the cement industry. Nonetheless, huge advancement has been made in recent years with the advent of vital research in sorption-enhanced water gas shift, underground gasification combined cycle, ammonium hydroxide solution, and the microbial-induced synthesis of calcite for $\mathrm{CO}_{2}$ capture and storage, all considered sustainable and feasible in cement production.

Supplementary Materials: The following are available online at https:/ / www.mdpi.com/article/10 .3390 /atmos12091111/s1, Figure S1: Carbon-dioxide $\left(\mathrm{CO}_{2}\right)$ emissions from 1970 to 2019 in Nigeria and other countries, Figure S2: Carbon-dioxide $\left(\mathrm{CO}_{2}\right)$ emissions from 1970 to 2019 in Nigeria [22], Figure S3: Methane $\left(\mathrm{CH}_{4}\right)$ emissions from 1970 to 2019 in Nigeria [22], Figure S4: Nitrous Oxide Emissions $\left(\mathrm{N}_{2} \mathrm{O}\right)$ from 1970 to 2019 in Nigeria [22], Figure S5: Fluorinated Greenhouse Gases (F-gases): HFCs, PFCs and SF6 Emission in Nigeria [22].

Author Contributions: The authors declare no conflict of interest Conceptualization: D.O., K.B.; Methodology, software, and validation: M.-A.E.; Writing-Original draft: M.-A.E., J.L.; Writingreview and editing: M.-A.E. and K.B.; Supervision: D.O. The authors disclose that no conflicting personal or financial interests exist which could interfere with this research's findings in any way. All authors have read and agreed to the published version of the manuscript.

Funding: This research received no external funding.

Institutional Review Board Statement: Not applicable.

Informed Consent Statement: Not applicable.

Data Availability Statement: Not applicable. 
Acknowledgments: The authors wholeheartedly appreciate the Chancellor and Managerial team of Covenant University for making this medium accessible for research publications.

Conflicts of Interest: The authors declare no conflict of interest.

\section{References}

1. Adeniran, J.A.; Yusuf, R.O.; Fakinle, B.S.; Sonibare, J.A. Air quality assessment and modelling of pollutants emission from a major cement plant complex in Nigeria. Atmos. Pollut. Res. 2019, 10, 257-266. [CrossRef]

2. Oni, A.; Fadare, D.; Adeboye, L. Thermoeconomic and environmental analyses of a dry process cement manufacturing in Nigeria. Energy 2017, 135, 128-137. [CrossRef]

3. Dunuweera, S.P.; Rajapakse, R.M.G. Cement Types, Composition, Uses and Advantages of Nanocement, Environmental Impact on Cement Production, and Possible Solutions. Adv. Mater. Sci. Eng. 2018, 2018, 1-11. [CrossRef]

4. Arachchige, U.S.; Amakm, A.; Balasuriya, B.M.C.M.; Chathumini, K.K.G.L.; Dassanayake, N.P.; Devasurendra, J.W. Environmental Pollution by Cement Industry. Int. J. Res. 2019, 6, 631-635.

5. Schneider, M.; Romer, M.; Tschudin, M.; Bolio, H. Sustainable cement production-present and future. Cem. Concr. Res. 2011, 41, 642-650. [CrossRef]

6. U. National Minerals Information Center, “CEMENT”. 2020. Available online: https://pubs.usgs.gov/periodicals/mcs2020/ mcs2020-cement.pdf (accessed on 6 January 2021).

7. International Energy Agency (IEA). Cement Technology Roadmap Plots Path to Cutting CO2 Emissions 24\% by 2050. 2018 Available online: https:/ / www.iea.org/news/cement-technology-roadmap-plots-path-to-cutting-co2-emissions-24-by-2050 (accessed on 6 January 2021).

8. Global Cement. CEMENT 101-An Introduction to the World's Most Important Building Material. 2011. Available online: https://www.globalcement.com/magazine/articles/490-cement-101-an-introduction-to-the-worlds-most-importantbuilding-material (accessed on 6 January 2021).

9. Ndefo, O. The contribution of the nigerian cement industry to global warming. Int. J. Eng. Sci. Technol. 2012, 4, 4691-4694.

10. Raw Material Research and Development Council. Chemical Analysis of Major Limestone and Marble in Nigeria.

11. WHO. 9 Out of 10 People Worldwide Breathe Polluted Air, but More Countries Are Taking Action. 2018. Available online: https:/ / www.who.int/news/item/02-05-2018-9-out-of-10-people-worldwide-breathe-polluted-air-but-more-countriesare-taking-action (accessed on 6 January 2021).

12. Sánchez-Soberón, F.; Rovira, J.; Mari, M.; Sierra, J.; Nadal, M.; Domingo, J.L.; Schuhmacher, M. Main components and human health risks assessment of PM10, PM2.5, and PM1 in two areas influenced by cement plants. Atmos. Environ. 2015, 120, 109-116. [CrossRef]

13. Adeyanju, E.; Okeke, C.A.U. Exposure effect to cement dust pollution: A mini review. SN Appl. Sci. 2019, 1, 1572. [CrossRef]

14. Olaniyi, O.A.; Olutimehin, I.O.; Funmilayo, O.A. Review of climate change and its effect on Nigeria ecosystem. Int. J. Rural Dev. Environ. Health Res. 2019, 3. [CrossRef]

15. Salas, D.A.; Ramirez, A.D.; Rodriguez, C.; Petroche, D.M.; Boero, A.; Duque-Rivera, J. Environmental impacts, life cycle assessment and potential improvement measures for cement production: A literature review. J. Clean. Prod. 2016, 113, 114-122. [CrossRef]

16. Ministry of Mines and Steel Development. Nigeria's Mining and Metal Sector-Investment Promotion Brochure. 2017. Available online: https: / /www.minesandsteel.gov.ng/wp-content/uploads/2017/10/Nigeria-Ministry-of-Solid-Minerals-InvestmentBrochureV14.pdf (accessed on 11 January 2021).

17. Shakirat, A.; Oluwashina, A. Nigeria Cement Sector Update-Increasing Competition amid Long-term Opportunities. 2019. Available online: https:/ / www.unitedcapitalplcgroup.com/wp-content/uploads/2019/09/Nigeria-Cement-Sector-Update-3. pdf (accessed on 10 January 2021).

18. USGS. What is the Difference between Global Warming and Climate Change? 2021. Available online: https://www.usgs. gov / faqs / what-difference-between-global-warming-and-climate-change-1?qt-news_science_products=0\#qt-news_science_ products (accessed on 8 January 2021).

19. Raajasubramanian, D.; Sundaramoorthy, P.; Baskaran, L.; Ganesh, K.S.; Chidambaram, A.A.; Jeganathan, M. Cement dust pollution on growth and yield attributes of groundnut (Arachis hypogaea L.). Int. Multidiscip. Res. J. 2011, 1, 31-36.

20. Garg, A.; Shukla, P.; Bhattacharya, S.; Dadhwal, V. Sub-region (district) and sector level SO2 and NOx emissions for India: Assessment of inventories and mitigation flexibility. Atmos. Environ. 2001, 35, 703-713. [CrossRef]

21. Wilson, J.; Law, S. Global Warming; Magpie Books: London, UK, 2007.

22. Olivier, J.G.J.; Peters, J.A.H.W. Trends in Global CO2 and Total Greenhouse Gas Emissions 2020. Report. Available online: www.pbl.nl/en (accessed on 7 January 2021).

23. Hossain, U.; Poon, C.S.; Lo, I.M.C.; Cheng, J.C. Comparative LCA on using waste materials in the cement industry: A Hong Kong case study. Resour. Conserv. Recycl. 2017, 120, 199-208. [CrossRef]

24. Ighalo, J.O.; Adeniyi, A.G. A perspective on environmental sustainability in the cement industry. Waste Dispos. Sustain. Energy 2020, 2, 1-4. [CrossRef] 
25. Feiz, R.; Ammenberg, J.; Baas, L.; Eklund, M.; Helgstrand, A.; Marshall, R. Improving the CO2 performance of cement, part I: Utilizing life-cycle assessment and key performance indicators to assess development within the cement industry. J. Clean. Prod. 2015, 98, 272-281. [CrossRef]

26. Hamouda, A.S.; Eldien, M.; Abadir, M. Carbon dioxide capture by ammonium hydroxide solution and its possible application in cement industry. Ain Shams Eng. J. 2020, 11, 1061-1067. [CrossRef]

27. World Business Council for Sustainable Development. Cement Technology Roadmap, Paris. 2009. Available online: https: / / cement.mineralproducts.org/documents/wbcsd-iea\%20cement\%20roadmap\%202009.pdf (accessed on 3 August 2021).

28. Wang, T.; Hovland, J.; Jens, K.J. Amine reclaiming technologies in post-combustion carbon dioxide capture. J. Environ. Sci. 2015, 27, 276-289. [CrossRef]

29. Feng, Y.; Yang, B.; Hou, Y.; Duan, T.-H.; Yang, L.; Wang, Y. Comparative environmental benefits of power generation from underground and surface coal gasification with carbon capture and storage. J. Clean. Prod. 2021, 310, 127383. [CrossRef]

30. Shen, L.; Gao, T.; Zhao, J.; Wang, L.; Wang, L.; Liu, L.; Chen, F.; Xue, J. Factory-level measurements on CO2 emission factors of cement production in China. Renew. Sustain. Energy Rev. 2014, 34, 337-349. [CrossRef]

31. Çankaya, S.; Pekey, B. A comparative life cycle assessment for sustainable cement production in Turkey. J. Environ. Manag. 2019, 249, 109362. [CrossRef]

32. Valderrama, C.; Granados, R.; Cortina, J.L.; Gasol, C.M.; Guillem, M.; Josa, A. Implementation of best available techniques in cement manufacturing: A life-cycle assessment study. J. Clean. Prod. 2012, 25, 60-67. [CrossRef]

33. Galvez-Martos, J.-L.; Schoenberger, H. An analysis of the use of life cycle assessment for waste co-incineration in cement kilns. Resour. Conserv. Recycl. 2014, 86, 118-131. [CrossRef]

34. Georgiopoulou, M.; Lyberatos, G. Life cycle assessment of the use of alternative fuels in cement kilns: A case study. J. Environ. Manag. 2018, 216, 224-234. [CrossRef]

35. Water Quality Monitoring and Assessment in a Developing Country. 2012, pp. 481-494. Available online: https: / / books.google.com/books?hl=en\&lr=\&id=z-uZDwAAQBAJ\&oi=fnd\&pg=PA481\&ots=pbRxU74Q8E\&sig=HwLEw5 llFFLospqJUdnL3tYs7VQ (accessed on 16 March 2021).

36. Ighalo, J.O.; Adeniyi, A.G. A comprehensive review of water quality monitoring and assessment in Nigeria. Chemosphere 2020, 260, 127569. [CrossRef] [PubMed]

37. Ekere, N.R.; Agbazue, V.E.; Ngang, B.U.; Ihedioha, J.N. Hydrochemistry and Water Quality Index of groundwater resources in Enugu north district, Enugu, Nigeria. Environ. Monit. Assess. 2019, 191, 150. [CrossRef] [PubMed]

38. Olukanni, D.O.; Ebuetse, M.A.; Anake, W.U. Drinking Water Quality and Sanitation Issues: A Survey of a Semi-Urban Setting in Nigeria. 2014. Available online: http:/ / covenantuniversity.edu.ng/Profiles/OLUKANNI-David-O (accessed on 16 March 2021).

39. Omole, D.O.; Isiorho, S.A. Waste Management and Water Quality Issues in Coastal States of Nigeria. The Ogun State Experience. J. Sustain. Dev. Afr. 2011, 13,1-11.

40. Inegbenebor, A.I.; Mordi, R.C.; Idowu, A.O.; Siyanbola, T.O.; Akanle, B.; Evbuoma, I.K.; Inegbenebor, A.O. Consequences of the activities of a Nigerian cement industry on the environment. Int. J. Appl. Nat. Sci. 2018, 7, 67-74.

41. Seiyaboh, E.I. A Review of Impacts of Gas Flaring on Vegetation and Water Resources in the Niger Delta Region of Nigeria. Int. J. Econ. Energy Environ. 2017, 2, 48. [CrossRef]

42. Galadima, A.; Garba, Z.N.; Leke, L.; Almustapha, M.N. Domestic Water Pollution among Local Communities in Nigeria-Causes and Consequences. 2011. Available online: http:/ / www.eurojournals.com/ejsr.htm (accessed on 16 March 2021).

43. Izah, S.C.; Srivastav, A.L. Level of arsenic in potable water sources in Nigeria and their potential health impacts: A review Scientifc research production of India and China in environmental chemistry: A bibliometric assessment View project Level of arsenic in potable water sources in Nigeria and their potential health impacts: A review. J. Environ. Treat. Tech. 2015, 3, 15-24.

44. Umoh, J.; Ikwa, L.; Uchendu, U. Effects of effluent discharge on man and soil ecosystem in Calabar, south southern Nigeria. J. Appl. Sci. Environ. Manag. 2019, 23, 1061. [CrossRef]

45. Sesugh, A.; Idowu, O.E.; Titus, A.; Zack, A.; Mavis, O.; Joseph, T. Physicochemical and Heavy Metal Analysis of Well Water obtained from Selected Settlements around Dangote Cement Factory in Gboko, Nigeria. ChemSearch J. 2019, 10, 94-99.

46. Meme, F.K.; Arimoro, F.O.; Nwadukwe, F.O. Analyses of Physical and Chemical Parameters in Surface Waters nearby a Cement Factory in North Central, Nigeria. J. Environ. Prot. 2014, 5, 826-834. [CrossRef]

47. Parithielamvazhuthi, R. Analysis of Air Pollutant Emission and Control System in Cement Industries around Ariyalur District. 2013. Available online: www.ijsr.net (accessed on 13 January 2021).

48. Ibanga, I.J.; Umoh, N.B.; Iren, O.B. Effects of Cement Dust on Soil Chemical Properties in the Calabar Environment, Southeastern Nigeria. Commun. Soil Sci. Plant Anal. 2008, 39, 551-558. [CrossRef]

49. Maina, H.M.; Egila, J.N.; Nkafamiya, I.I.; Shagal, M.H. Impact of cement dust deposition on the elemental composition of soils in the vicinity of Ashaka cement factory, Nigeria. Int. Res. J. Agric. Sci. Soil Sci. 2013, 3, 66-74.

50. Egbe, E.R.; Nsonwu-Anyanwu, A.C.; Offor, S.J.; Opara Usoro, C.A.; Etukudo, M.H. Heavy metal content of the soil in the vicinity of the united cement factory in Southern Nigeria. J. Adv. Environ. Health Res. 2019, 7, 122-130. [CrossRef]

51. Asubiojo, O.I.; Aina, P.O.; Oluwole, A.F.; Arshed, W.; Akanle, O.A.; Spyrou, N.M. Effects of cement production on the elemental composition of soils in the neighborhood of two cement factories. Water Air Soil Pollut. 1991, 57, 819-828. [CrossRef] 
52. Wufem, M.B.; Ibrahim, A.Q.; Maina, H.M.; Nangbes, J.G.; Nvau, J.B. Speciation of Some Heavy Metals in Soils Around a Cement Factory in Gombe State, Nigeria. Available online: http:/ / repository.plasu.ngren.edu.ng:8080/xmlui/handle/123456789/346 (accessed on 12 January 2021).

53. Hua, S.; Tian, H.; Wang, K.; Zhu, C.; Gao, J.; Ma, Y.; Xue, Y.; Wang, Y.; Duan, S.; Zhou, J. Atmospheric emission inventory of hazardous air pollutants from China's cement plants: Temporal trends, spatial variation characteristics and scenario projections. Atmos. Environ. 2016, 128, 1-9. [CrossRef]

54. Zhang, T.; Wu, C.; Li, B.; Wang, J.; Ravat, R.; Chen, X.; Wei, J.; Yu, Q. Linking the SO2 emission of cement plants to the sulfur characteristics of their limestones: A study of 80 NSP cement lines in China. J. Clean. Prod. 2019, 220, 200-211. [CrossRef]

55. Amin, R.M. A study of radon emitted from building materials using solid state nuclear track detectors. J. Radiat. Res. Appl. Sci. 2015, 8, 516-522. [CrossRef]

56. Abdul-Wahab, S.A. Impact of fugitive dust emissions from cement plants on nearby communities. Ecol. Model. 2006, 195, 338-348. [CrossRef]

57. Gbadebo, A.; Amos, A. Assessment of Radionuclide Pollutants in Bedrocks and Soils from Ewekoro Cement Factory, Southwest Nigeria. Asian J. Appl. Sci. 2010, 3, 135-144. [CrossRef]

58. Cassee, F.R.; Héroux, M.-E.; Gerlofs-Nijland, M.E.; Kelly, F.J. Particulate matter beyond mass: Recent health evidence on the role of fractions, chemical constituents and sources of emission. Inhal. Toxicol. 2013, 25, 802-812. [CrossRef]

59. Schlesinger, R.B. The Health Impact of Common Inorganic Components of Fine Particulate Matter (PM2.5) in Ambient Air: A Critical Review. Inhal. Toxicol. 2007, 19, 811-832. [CrossRef] [PubMed]

60. World Bank. A Plea for Action against Pollution in Nigeria. 2015. Available online: https://www.worldbank.org/en/news/ feature/2015/06/16/in-lagos-nigeria-a-plea-for-action-against-pollution (accessed on 13 January 2021).

61. Croitoru, L.; Chang, J.C.; Kelly, A. The Cost of Air Pollution in Lagos. 2020. Available online: https:/ / openknowledge.worldbank. org/handle/10986/33038 (accessed on 12 January 2021).

62. Emetere, M.; Dania, E. Short review on air pollution from cement factories. J. Physics Conf. Ser. 2019, 1299, 012033. [CrossRef]

63. Abimbola, A.F.; Kehinde-Phillips, O.O.; Olatunji, A. The Sagamu cement factory, SW Nigeria: Is the dust generated a potential health hazard? Environ. Geochem. Health 2007, 29, 163-167. [CrossRef]

64. Nwachukwu, A.N.; Chukwuocha, E.O.; Igbudu, O. A survey on the effects of air pollution on diseases of the people of Rivers State, Nigeria. Afr. J. Environ. Sci. Technol. 2012, 6, 371-379. [CrossRef]

65. Olaleye, V.F.; Oluyemi, E.A. Effects of cement flue dusts from a Nigerian cement plant on air, water and planktonic quality. Environ. Monit. Assess. 2009, 162, 153-162. [CrossRef] [PubMed]

66. Ugwuanyi, J.U.; Obi, F.C. A Survey of Health Effects Of Air Pollution On Peasant Farmers In Benue State, Nigeria. Int. J. Environ. Stud. 2002, 59, 665-677. [CrossRef]

67. Otaru, A.J.; Odigure, J.O.; Okafor, J.O.; Abdulkareem, A.S. Investigation into Particulate Pollutant Concentration From A Cement Plant: A Case Study Of Obajana Cement Plc, Lokoja, Nigeria. IOSR J. Environ. Sci. Toxicol. Food Technol. 2013, 3, 56-62. [CrossRef]

68. Temitope, P.; Ogochukwu, E.I. Impact of Air Pollution on the Microbiological Quality of Ready to Eat Hawked Foods Sold around a Cement Factory in Lokoja, Nigeria. 2014. Available online: www.usa-journals.com (accessed on 12 January 2021).

69. Ideriah, T.; O Stanley, H. Air quality around some cement industries in Port Harcourt, Nigeria. Sci. Afr. 2009, 7, 27-34. [CrossRef]

70. Otaru, O.; Okafor, J.O.; Abdulkareem, A.S. Model Prediction of Particulate Dispersion from a Cement Mill Stack: Case Study of a Cement Plant in Nigeria. 2013. Available online: www.Iosrjournals.Org (accessed on 12 January 2021). 